\title{
基于模型耦合的土地利用变化和 水文响应多情景分析
}

\author{
张 凌 1,2 , 南卓铜 $1^{*}$, 余文君 ${ }^{1}$ \\ (1. 中国科学院寒区早区环境与工程研究所,兰州 730000; 2. 中国科学院大学, 北京 100049)
}

\begin{abstract}
摘要: 排放情景下未来气候变化和土地利用变化及其水文响应是流域管理十分关心的问题。本文通过耦合土地利 用/覆被变化模型Dyna-CLUE 和水文模型 SWAT, 选择政府间气候变化专门委员会(IPCC)发布的两个温室气体排 放情景 (A1B 和 B1), 对黑河流域中上游土地利用变化及水文响应进行情景分析。模型校准和验证结果表明, Dyna-CLUE 和 SWAT 的模拟精度均比较满意。土地利用变化情景分析表明,不同排放情景下未来黑河流域中上游土 地利用变化幅度均不大, 同一情景下土地利用变化在中上游表现出各自的特点。水文响应多情景分析表明, 不考 虑土地利用变化, 相对于参考情景即以 1990-2009年历史数据模拟结果, 高排放 A1B 情景下黑河流域上游和中游 2011-2030年年平均河川径流分别呈微弱减少和明显增加的趋势, 而低排放 B1 情景下分别呈明显减少和微弱减少 的趋势。同一情景下, 水文响应具有明显的区域差异性。考虑土地利用变化, 高排放 A1B 情景下黑河流域上游和 中游 2011-2030年年平均河川径流分别小于和大于不考虑土地利用变化的情况, 低排放 B1 情景下均小于不考虑 土地利用变化的情况。分析表明, 排放情景下气候变化和土地利用变化导致流域水文水资源的变化,而土地利用 变化可能加剧或削弱气候变化导致的水文响应。
\end{abstract}

关键词: 模型耦合; 土地利用变化; 水文响应; 情景分析

DOI: $10.3724 /$ SP.J.1047.2013.00829

\section{1 引言}

黑河流域是我国西北干旱区典型的内陆河流 域, 受中部高纬度西风带环流的控制和极地冷气团 的影响, 气候干旱、风大沙多、土地贫瘦、自然条件 恶劣、生态环境严酷和脆弱, 并且呈不断恶化的趋 势 ${ }^{[1-3]}$ 。因此, 保持黑河流域生态不再继续退化、恶 化, 促进黑河流域生态建设成为目前广泛关注和函 需解决的问题。

土地利用变化和水文响应是流域生态环境中 十分重要的问题, 尤其是在干旱的内陆河流域—— 黑河流域, 土地利用和水文响应变化对流域生态系统 结构和功能具有重要的影响 ${ }^{[4.5]}$ 。气候和土地利用变 化是其中的两个重要影响因素, 而且气候变化会伴随 着土地利用的变化,两者又共同影响水文响应 ${ }^{[6-8]}$ 。

目前, 黑河流域土地利用变化的研究有: 蒙吉
军等利用遥感影像解译的 1995 年和 2000 年的土地 利用图, 对黑河流域 5 年来的土地利用与覆盖变化 研究, 表明土地利用变化的区域差异显著、区域城 镇化加快和生态环境不断恶化 ${ }^{[9]}$; 李传哲等利用 1995 、2000 和 2005 年 3 期不同遥感影像解译的土地 利用图, 对黑河干流中游地区土地利用/覆盖的变化 及其驱动力的研究, 结果表明研究区土地利用发生 了巨大的变化, 社会经济因子是主要的驱动力 ${ }^{[10]}$; 姜朋辉等以 1975、1987、1992、2001 和2010年遥感 影像为基础数据, 对黑河流域中游地区近 35 年来的 土地利用/覆盖变化及驱动力综合分析, 结果表明, 耕地和城乡居民工矿用地持续增加, 草地和水域不 断减少, 主要的驱动力为社会经济因素 ${ }^{[1]}$ 。然而, 这些研究均采用历史的土地利用数据分析研究区 的土地利用变化特征及规律, 很少利用土地利用/覆 盖变化模型对土地利用变化进行动态模拟及预

收稿日期: 2013-11-08; 修回日期: 2013-12-30.

基金项目: 国家自然科学基金项目(91125006)。

作者简介: 张 凌(1988-), 四川巴中人, 硕士生, 主要从事水文水资源的情景分析研究。E-mail:zhanglingky@126.com *通讯作者: 南卓铜 (1977-), 浙江乐清人, 研究员, 研究方向为水文水资源决策支持系统和建模及环境研究。 
测。此外, 张华等在 3 种不同的水资源情景下, 应用 CLUE-S 模型对黑河流域中上游张掖市的土地利用 变化进行了模拟, 结果表明, 耕地、城镇用地都在增 加, 林地和草地都在减少, 水域变化不明显 ${ }^{[12]}$ 。然 而, 此研究在情景的设置上仅考虑了水资源状况, 而对决策者可能关心的温室气体排放情景下的土 地利用变化研究相对较少。

关于黑河流域水文响应分析, 吴志勇等利用 VIC 模型, 在不同气候变化情景下, 对黑河流域极 端水文事件的响应进行了分析, 结果表明相对于参 考时期, 在不同气候变化情景下, 洪水和枯水事件 均呈现增加的趋势 ${ }^{[13]}$ 。陈亮设置了 15 种不同的气 候变化情景, 对黑河流域上游径流响应进行了模 拟, 结果表明径流和温度成反比的关系, 和降水呈 正比的关系 ${ }^{[14]}$ 。这些研究基于单一的水文模型, 通 过一些简单假设法来分析不同气候变化情景下的 水文响应, 这是不充分的, 因为气候变化伴随的土 地利用变化也一样影响到水文响应。因此, 我们需 要通过耦合土地利用变化模型和水文模型, 考虑气 候变化和土地利用变化对水文响应的共同影响进 行多情景分析。

本研究通过耦合土地利用/覆盖变化模型 Dyna-CLUE 和水文模型 SWAT, 选择政府间气候变化 专门委员会 (IPCC) 发布的两个温室气体排放情景 (高排放 A1B 和低排放 B1), 对黑河流域中上游土 地利用变化及水文响应进行多情景分析, 以期为黑 河流域河流土地利用和水资源规划管理提供科学 的依据。

\section{2 研究区及数据}

（1）黑河流域是中国西北典型的内陆河流域, 位于河西走廊和祁连山中段, 南北跨越青海、甘肃、 内蒙古 3 省 (自治区)。本研究区为黑河流域中上游 地区 (图 1), 是从黑河干流源头 (祁连山) 到正义峡 之间的流域。上游祁连山地是流域的产流区, 中游 走廊平原集中了全流域 $90 \%$ 以上的耕地和人口, 是 流域的主要用水区。同时, 为了对该区域有限的水 资源进行开发利用和精细管理, 中游走廊平原逐渐 形成了十分密集和发达的人工渠系。

(2) 研究数据包括 IPCC 数据, Dyna-CLUE 模型 数据和 SWAT 模型数据。IPCC 数据为服务于第 4 次报告的 $\mathrm{HadCM} 3$ 模型在排放情景 (A1B 和 B1)下
模拟的全球尺度的降雨和温度数据 (http://www. ipcc-data.org/sim/gcm_monthly/SRES_AR4/index.ht$\mathrm{ml}$ ), 时间序列为 1980-2030年, 时间分辨率为月, 空 间分辨率为 $2.5^{\circ} \times 3.75^{\circ}$ (纬度 $\times$ 经度)。Dyna-CLUE 模型数据主要包括土地利用数据和模型驱动数据, 均来自于寒区旱区科学数据中心 (http://westdc. westgis.ac.cn)。土地利用数据包括 1986 年和 2000 年覆盖整个黑河流域的土地利用/覆盖数据集, 张掖 地区 2005 年土地利用/覆盖数据集; 驱动变量包括 $\mathrm{DEM}$ 、坡度、坡向、土壤类型、到公路的距离、到铁路 的距离、到河流的距离、到水库的距离、到居民点的 距离、地均 GDP、人均 GDP 和人口密度, 所有数据 均统一到 WGS Albers 投影系统, 空间分辨率为 $300 \mathrm{~m}$ 。SWAT 模型数据主要包括 DEM 数据、土壤 数据、土地利用数据和气象数据。DEM数据、土壤 数据及土地利用数据 (2000年) 均来源于寒区早区 科学数据中心, 数据均统一到WGS Albers 投影系 统, 空间分辨率为 $300 \mathrm{~m}$ 。气象数据包括鼎新、酒 泉、高台、张掖、山丹、托勒、野牛沟、祁连、永昌共 9 个气象站点的降水、气温、相对湿度和风速等数据, 时序为 1980-2009年, 数据来源于中国气象科学数 据共享网 (http://cdc.cma.gov.cn/home.do)。为了提 高SWAT 模型模拟精度, 本研究选择 10 个高程不同 的插值站点 (图 1), 采用 MicroMet 对其降雨进行插 值 ${ }^{[15]}$, 这些插补站点的引入可提高 SWAT 对气象要 素插值的精度。

\section{3 模型耦合的多情景分析}

\section{1 模型分析}

Dyna-CLUE (Dynamic Conversion of Land-Use and its Effects Model) 模型是一个考虑土地类型之 间竞争关系, 能够定量描述土地利用变化空间分布 的多尺度土地利用变化模型 ${ }^{[16-18]}$ 。模型由两个模块 组成, 即非空间分析模块 (土地利用需求模块) 和空 间分析模块 (土地空间分配模块)。运行 Dyna-CLUE模型需要 5 种类型的数据, 包括土地需求 数据、空间特征数据、邻域特征数据、空间政策限制 数据和土地利用类型之间的转换参数。

Dyna-CLUE模型模拟结果的验证, 采用图像分 类精度常用的一种评价方法一一错误矩阵, 它是通 过将参考图像中每个像元的位置和分类与分类图 像中相应的位置和分类相比较计算得到的 ${ }^{[19]}$ 。本 


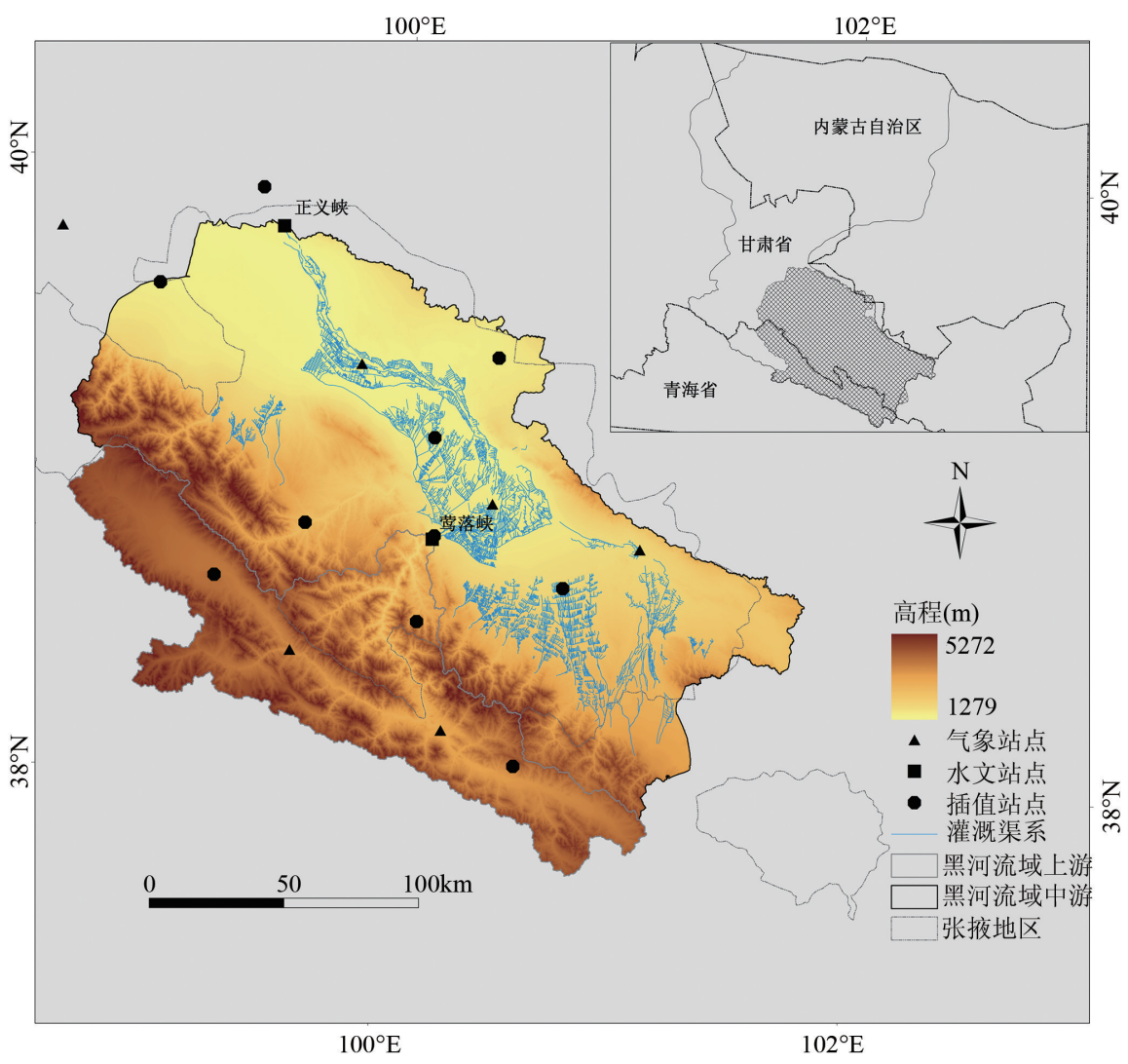

图 1 研究区位置

Fig.1 Location of the study area

研究选择黑河流域中上游 2000 年及中游张掖地区 2000、2005年土地利用图对模型进行验证。

SWAT (Soil and Water Assessment Tool) 模型是 美国农业部下属的农业研究所开发的具有物理基 础的分布式水文模型, 是分析土地利用变化和气候 变化对水文影响的一个重要工具 ${ }^{[20]}$ 。在 SWAT 模型 中, 首先根据流域出水口位置及 DEM, 将流域划分 为许多子流域, 然后再根据土地利用数据、土壤数 据及坡度数据将子流域划分为许多水文响应单元 (HRUs, Hydrological response Units), 最后以水文 响应单元为基础, 模拟流域中水、沙和化学物质的 运输和转移过程。

本研究中, SWAT 模型校准和验证选择黑河流 域上游出口莺落峡和中游出口正义峡出口月径流 观测数据。上游莺落峡站径流观测值受到水库的 影响而呈现非自然径流状态, 因此, 本研究分别采 用黑河流域上游蕮落峡站月径流观测数据的还原 值及中游正义峡站月径流观测数据对 SWAT 模型 进行校准和验证 ${ }^{[21]}$ 。校准期时段分别为 1990-1999 年、2000-2004 年; 验证期时段分别为 2000-2009 年、2005-2009年。1989年作为 SWAT 模型的预热
阶段,假定校准好的 SWAT 模型参数在后面水文响应 情景分析中仍然适用。本研究在参考已有文献的基 础上, 对 SWAT 模型采用试错法进行手动校准 ${ }^{[21-23]}$, 模 型校准和验证结果采用 Nash 效率系数(Ens) 和相关 系数 $\mathrm{R}^{2}$ 进行评价。

\section{2 排放情景}

A1B、B1 情景是政府间气候变化专门委员会 (IPCC) 发布的 2 个温室气体和气溶胶排放情景。 $\mathrm{A} 1 \mathrm{~B}$ 情景描述了这样一个未来世界: 经济增长非常 快, 全球人口数量峰值出现在本世纪中叶并随后下 降, 新的更高效的技术被迅速引进, 在所有能源供 给和终端利用技术平行发展的假定下, 不过分依赖 于某种特定能源, 对未来温室气体排放持悲观状态 (高排放)。B1 情景描述了一个趋同的未来世界: 人 口变化和 $\mathrm{A} 1 \mathrm{~B}$ 情景相似, 强调社会、经济和环境可 持续发展的全球解决方案, 其中, 包括公平性的提 高, 不采用额外的气候政策干预。与 A1B 情景不 同, B1 情景是经济结构向服务和信息经济方向迅速 调整, 伴之以材料密集程度下降和清洁能源和资源 高效利用, 强调社会公平和环境保护, 对未来温室 
气体排放持乐观状态 (低排放)。

在不同排放情景下, 未来气象数据( 降雨和气 温)选择服务于 IPCC 第 4 次报告的 HadCM3 模型 在全球尺度的模拟结果, 利用较简单 Delta 降尺度 方法 ${ }^{[24-25]}$, 对 HadCM3 模型模拟结果进行降尺度处 理, 构建黑河流域中上游在 A1B、B1 情景下 20112030 年的降雨和温度数据。

在不同排放情景下,未来土地利用需求特征数 据参考日本国立环境研究所的亚太地区综合模型 (Asia-Pacific Integrated Model, AIM) 在 ASIAP (China and central planned Asia, South and East Asia) 区 域模拟结果 ${ }^{[26-27]}$, 具体需求特征见表 1 。根据排放情 景下土地需求特征, 利用 Dyna-CLUE 模型模拟黑 河流域中上游未来土地利用变化。

表 $1 \mathrm{~A} 1 \mathrm{~B}$ 和 B1 情景下黑河流域中上游土地需求特征

Tab.1 Land use demand characteristics in the upper and middle reaches of Heihe River Basin with A1B and B1 scenarios

\begin{tabular}{lll}
\hline 土地利用类型 & \multicolumn{1}{c}{ A1B } & \multicolumn{1}{c}{ B1 } \\
耕地、林地、草地 AIM 模拟 & AIM 模拟 \\
水域 & 保持2000年面积不变 & 保持2000年面积不变 \\
建设用地 & 随ASIAP区域的人口 & 随ASIAP区域的人口 \\
& 趋势变化 & 趋势变化 \\
未利用地 & 剩下的土地面积 & 剩下的土地面积 \\
空间政策限制 & 无空间限制政策 & 设置坡度大 25\%的林 \\
& & 地和草地为限制区域 \\
\hline
\end{tabular}

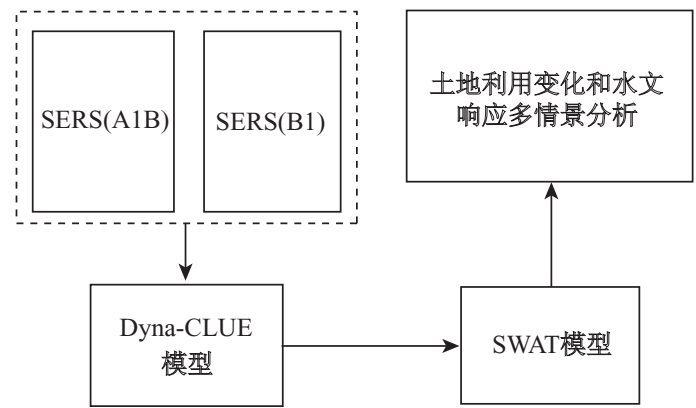

图 2 模型耦合

Fig.2 Schema of model coupling

\section{3 模型耦合}

本研究模型耦合为单向的耦合方式 (图 2), 首 先, 在不同排放情景 (A1B 和 B1) 下, 利用 Dyna-CLUE 模型模拟黑河流域中上游在 2011-2030年 的土地利用变化, 然后, 将不同情景下模拟的 2015、 2020、2025 和 2030 年土地利用图输入到 SWAT 模 型, 实现 Dyna-CLUE 模型和 SWAT 模型的耦合, 并 对黑河流域中上游土地利用变化和水文响应进行 情景分析。

\section{4 结果与分析}

\subsection{1 模型验证}

利用黑河流域中上游 2000 年及中游张掖地区 2000、2005 年土地利用现状图对 Dyna-CLUE 模型 模拟精度验证, 如表 2 所示。结果表明, 中上游

表 2 黑河流域中上游及中游张掖地区模型模拟精度验证结果

Tab.2 Validations of the model simulation in the upper and middle reaches of Heihe River Basin and in the Zhangye area located in the middle reaches

\begin{tabular}{|c|c|c|c|c|c|c|c|}
\hline \multirow{2}{*}{ 地区和年份 } & \multirow{2}{*}{ 总体精度 } & \multicolumn{6}{|c|}{ 制图精度 } \\
\hline & & 耕地 & 林地 & 草地 & 水域 & 建设用地 & 未利用地 \\
\hline 中上游 2000年 & 0.92 & 0.89 & 0.90 & 0.92 & 0.83 & 0.75 & 0.94 \\
\hline 中游张掖 2000 年 & 0.92 & 0.89 & 0.90 & 0.91 & 0.82 & 0.75 & 0.95 \\
\hline 中游张掖 2005 年 & 0.90 & 0.83 & 0.88 & 0.89 & 0.72 & 0.71 & 0.95 \\
\hline
\end{tabular}

2000 年及中游张掖地区 $2000 、 2005$ 年土地利用分 布模拟的总体精度均大于等于 0.90 ; 耕地、林地、草 地和未利用地模拟精度均较高 (最小制图精度为 $0.83)$; 建设用地模拟精度相对较低, 这主要是因为 建设用地变化容易受政策、人为等不确定性因素的 影响, 而这些因素在模型中没有得到充分的考虑; 2005 年中游张掖地区水域模拟精度相对较低, 这与 黑河流域在 2000 年及之后的分水政策有关 ${ }^{[10,28]}$ 。

黑河流域上游出口莺落峡月径流数据还原值
与模拟值对比结果如图 3 所示, 校准期 (1990-1999 年) Ens 为 0.88, $\mathrm{R}^{2}$ 为 0.92, 验证期 (2000-2009 年) Ens 为 $0.86, R^{2}$ 为 0.88 (表 3 )。黑河流域中游出口正 义峡月径流模拟值与观测值对比结果如图 4 所示, 校准期 (2000-2004 年) Ens 为 0.63, $\mathrm{R}^{2}$ 为 0.69; 验证 期 (2005-2009年) Ens 为 $0.60, R^{2}$ 为 0.72 (表 3 )。与 茑落峡相比, 正义峡径流模拟精度相对较低, 这与 黑河流域中游人类活动密集及复杂的人工灌溉渠 系系统有关。总体上, 黑河流域中上游两个径流观 


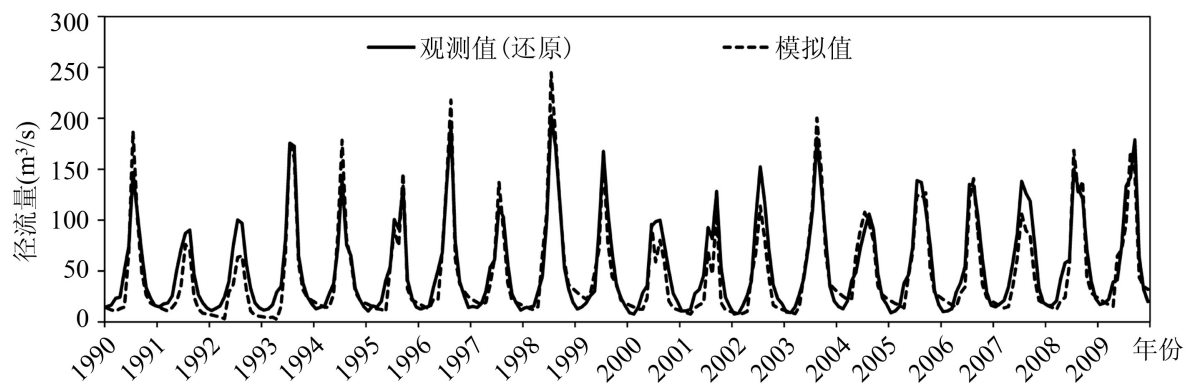

图 3 莺落峡站月径流观测值和模拟值

Fig.3 Monthly measured and simulated streamflow at the Yingluoxia station

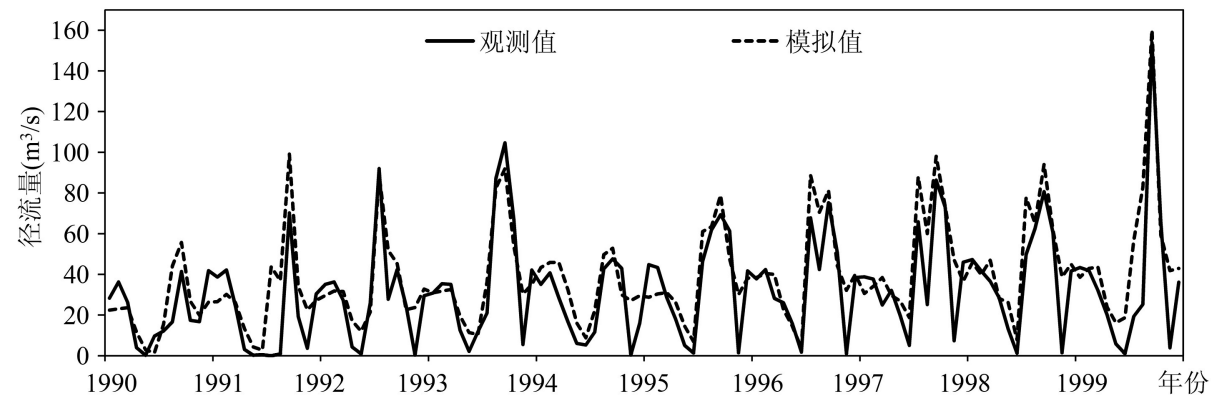

图 4 正义峡站月径流观测值和模拟值

Fig.4 Monthly measured and simulated streamflow at the Zhengyixia station

测站月径流量在校准和验证期模拟效果比较满意, 满足模拟精度的要求 ${ }^{[29-30]}$ 。

表 3 校准期和验证期月径流模拟精度评价结果

Tab.3 Model assessment of the monthly simulated streamflow

\begin{tabular}{cccc}
\hline 站点 & 时间段 & $\mathrm{R}^{2}$ & Ens \\
\hline 莺落峡 & 校准期 & 0.92 & 0.88 \\
& 验证期 & 0.88 & 0.85 \\
\multirow{2}{*}{ 正义峡 } & 校准期 & 0.69 & 0.63 \\
& 验证期 & 0.72 & 0.60 \\
\hline
\end{tabular}

\section{4 .2 土地利用变化情景分析}

(1)高排放情景 (A1B)

在 A1B 情景下, 相对于 2000 年的土地利用图 （图 5(a)），黑河流域中上游 2015、2020、2025 和 2030 年土地利用模拟的分布图 (图 5(b)-(e)) 空间 分布差异不明显,因此, 在 A1B 情景下黑河流域中 上游未来土地利用变化幅度不大。在 $\mathrm{A} 1 \mathrm{~B}$ 情景下, 相对于 2000 年, 黑河流域中上游 2011-2030 年耕 地、水域和未利用地呈现减少的趋势, 林地、草地和 建设用地呈现增加的趋势, 变化面积最大的土地类 型为未利用地, 至 2030 年, 减少的未利用地面积占
黑河流域中上游总面积的 $0.92 \%$ 。如果只考虑上游 区域, 2011-2030年耕地、林地、草地和建设用地均 表现为增加的趋势, 水域和未利用地呈减少的趋 势, 变化面积最大的地类仍为未利用地, 至 2030 年, 减少的未利用地面积占上游总面积的 $2.83 \%$ 。总体 上, A1B 情景下黑河流域中上游区域及单独的上游 地区土地利用变化幅度均不大, 但是, 在不同区域 变化趋势和幅度均不一样, 因此, 土地利用变化区 域差异明显。

(2)低排放情景 (B1)

黑河流域中上游 2000 年土地利用图和 B1 情景 模拟 2015、2020、2025 和 2030年土地利用分布如图 6 所示。相对于 2000 年土地利用图, B1 情景下模拟 的土地利用图空间分布差异不明显, 表明黑河流域 中上游土地利用变化幅度也不大。在 $\mathrm{B} 1$ 情景下, 相对于 2000 年, 黑河流域中上游 2011-2030 年耕 地、水域和未利用地呈现减少的趋势, 林地、草地和 建设用地呈现增加的趋势, 变化面积最大的仍为未 利用地, 至 2030 年, 减少的未利用地面积占黑河流 域中上游总面积的 $1.36 \%$ 。对于上游区域, B1 情景 下, 耕地、林地、草地和建设用地均表现为增加的趋 势, 水域和未利用地呈减少的趋势, 变化面积最大 


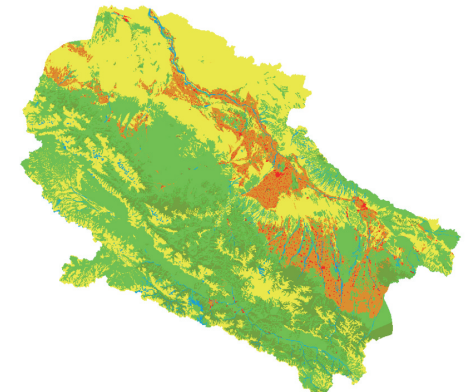

(a) 2000年参考图

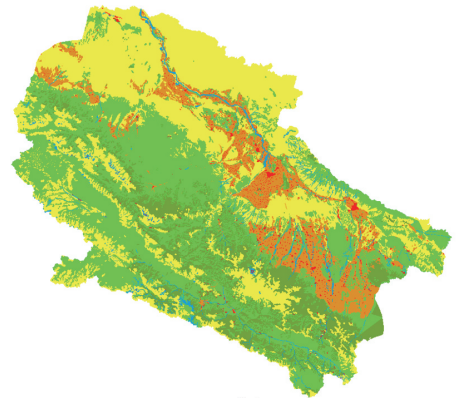

(d) 2025 年

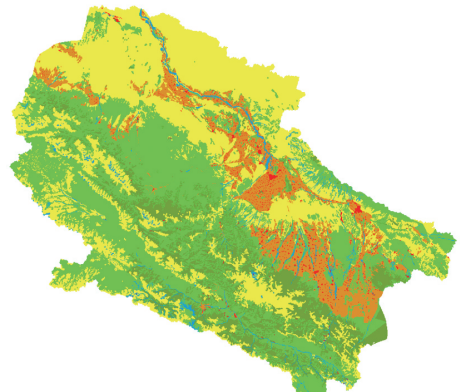

(b) 2015 年

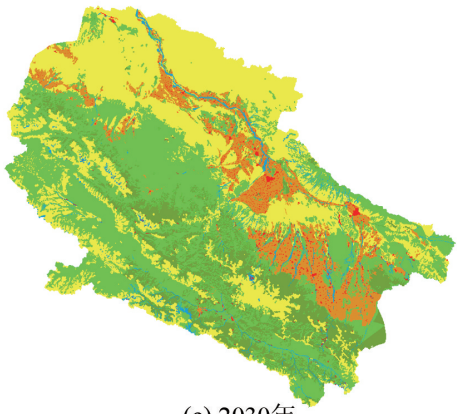

(e) 2030年

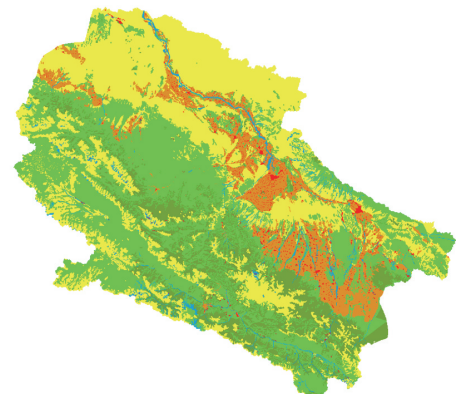

(c) 2020 年

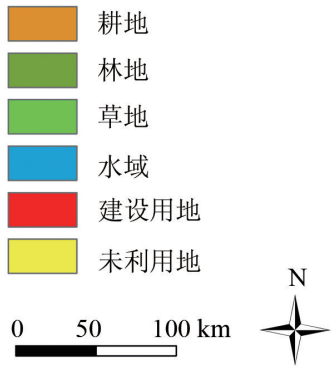

图 5 黑河流域中上游 A1B 情景下的土地利用模拟分布图

Fig. 5 Land use maps of the upper and middle reaches of Heihe River Basin under the A1B scenario

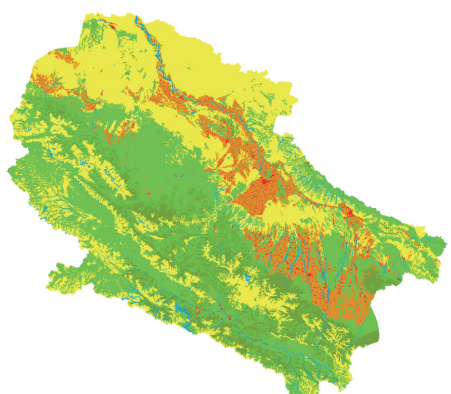

(a) 2000年参考图

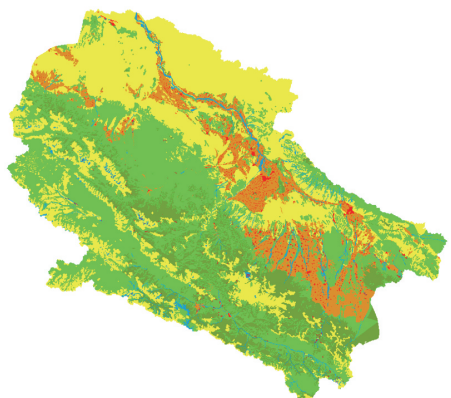

(d) 2025 年

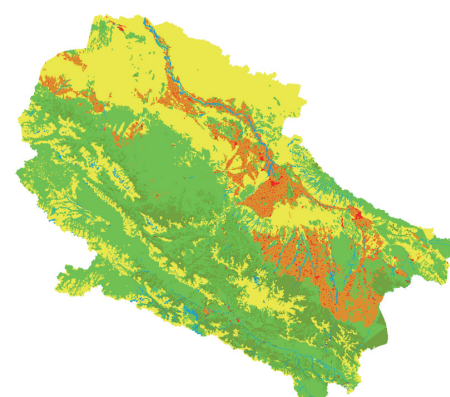

(b) 2015年

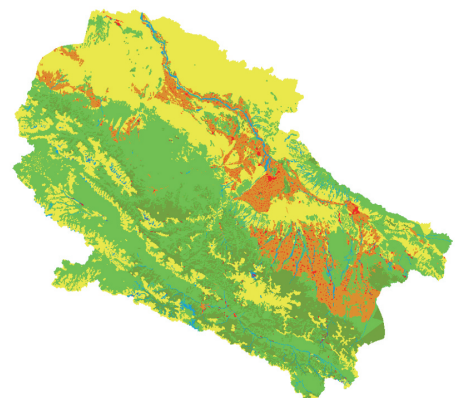

(e) 2030 年

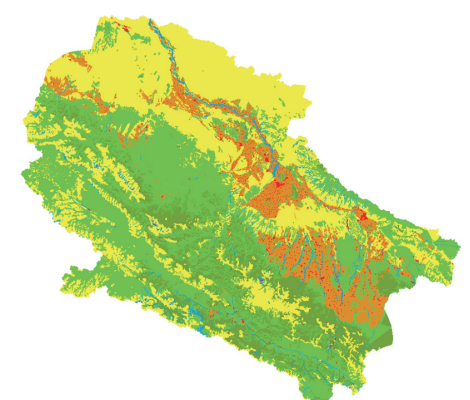

(c) 2020 年

图 6 黑河流域中上游 $\mathrm{B} 1$ 情景下模拟的土地利用分布图

Fig.6 Land use maps of the upper and middle reaches of Heihe River Basin under the B1 scenario

的仍为未利用地, 至 2030 年减少的未利用地面积占 上游总面积的 $3.63 \%$ 。总体上, 低排放的 B1 情景下 黑河流域中上游区域及上游地区土地利用变化幅 度均不大, 但是, 在上游和中上游变化趋势和幅度
均不一样, 土地利用变化区域差异明显。

(3) 情景分析

在 A1B 和 B1 情景下, 相对于 2000 年, 黑河流域 中上游 2011-2030 年耕地、水域和未利用地均呈现 
减少的趋势, 林地、草地和建设用地均呈现增加的 趋势, 但是不同情景下变化幅度不一样(图 7), 至 2030 年, B1 情景下林地和草地增加的面积及未利 用地减少面积明显大于 $\mathrm{A} 1 \mathrm{~B}$ 情景。因此, 未来黑河 流域中上游生态用地 (林地和草地) 在低排放情景 (B1) 的面积大于高排放情景 (A1B)。

在 $\mathrm{A} 1 \mathrm{~B}$ 和 $\mathrm{B} 1$ 情景下, 黑河流域上游在 2011-2030年耕地、林地、草地和建设用地均表现为 增加的趋势, 水域和未利用地均呈减少的趋势, 与 中上游地区相似,上游地区不同情景下不同土地利 用类型变化幅度也不一样(图 8)。分析表明,即使 在同一情景下, 上游和中上游地区土地利用面积相 对变化量不同, 如草地和未利用地面积在上游相对 变化量明显大于中上游地区 (图 7、8), 即土地利用 变化具有明显的区域性。

\section{4 .3 水文响应情景分析}

排放情景下气候变化和土地利用变化均会导

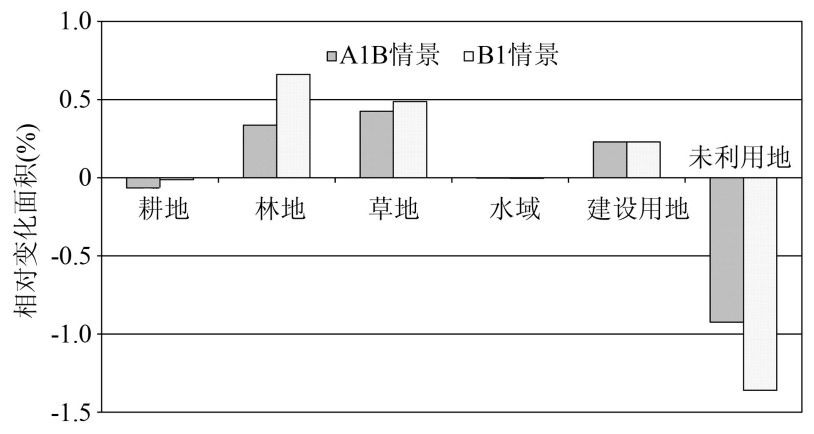

图 7 不同情景下黑河流域中上游2000-2030年各地类面积 相对变化

Fig.7 Relative land use change in the upper and middle reaches of Heihe River Basin between 2000 and 2030 under different scenarios

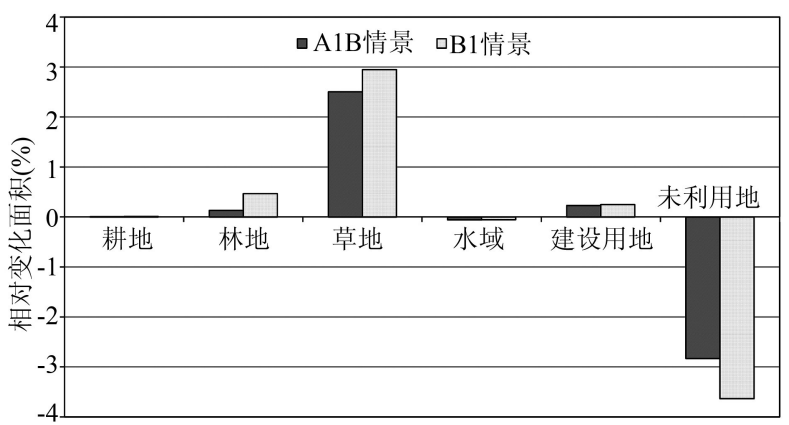

图 8 不同情景下黑河流域上游2000-2030年各地类面 积相对变化

Fig. 8 Relative land use change in the upper reache of Heihe River Basin between 2000 and 2030 under different scenarios
致水文水资源的变化, 因此本文分两种情况（不考 虑土地利用变化和考虑土地利用变化) 和两个区域 (上游和中游地区) 分析不同排放情景下的水文响 应。其中, 不考虑土地利用变化情况即未来只考虑 排放情景下气候变化的水文响应; 考虑土地利用变 化的情况即综合考虑排放情景下土地利用变化和 气候变化对水文水资源共同影响。同时, 为了方便 比较, 将 1990-2009年历史气象数据和历史土地利 用数据 (2000 年) 驱动 SWAT 模型模拟的结果作为 参考情景。

\section{(1) 高排放情景 (A1B)}

不考虑土地利用变化, 相对于参考情景, A1B 情景下黑河流域上游模拟的 2011-2030年年平均河 川径流呈微弱减少趋势, 且年平均河川径流的年内 分配在 5-10 月份差异较明显, 特别是夏季 (6-8 月) (图 9(a))。A1B 情景下未来河川径流的变化是由 于该情景下未来降雨和温度发生了变化(其他气象 因素假设和参考情景一致)。A1B 情景下未来降雨 年内分配如图 10(a) 所示, 多年年平均降雨量与河 川径流的年内分配相似, 与参考情景相比, 在 5-10 月降雨量差异较大, 尤其是夏季, 这也表明降雨对 黑河流域上游河川径流有直接的影响。A1B 情景 下未来多年月平均最高温度年内分配如图 11 所示, 和参考情景相比, 多年月平均最高温度在多数月份

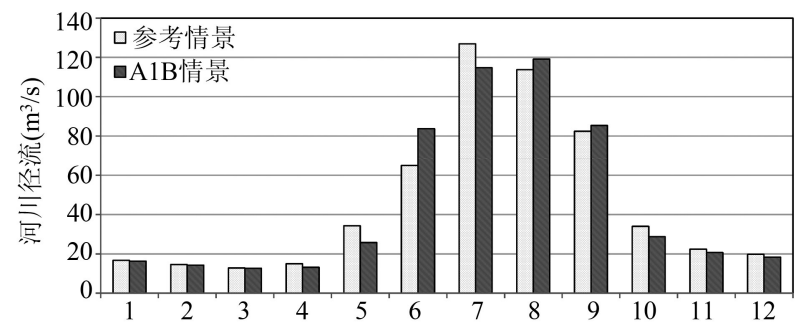

(a)上游

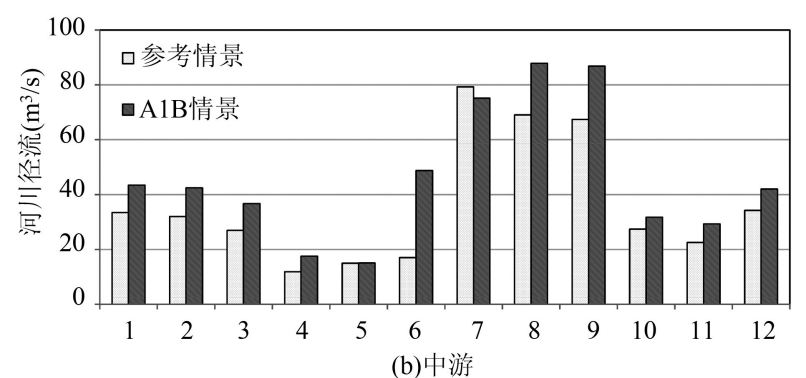

图 9 参考情景和 $\mathrm{A} 1 \mathrm{~B}$ 情景下黑河流域中、上游多年年平 均河川径流年内分配

Fig.9 Annual streamflow distribution in the upper and middle reaches of Heihe River Basin under the reference and $\mathrm{A} 1 \mathrm{~B}$ scenarios 


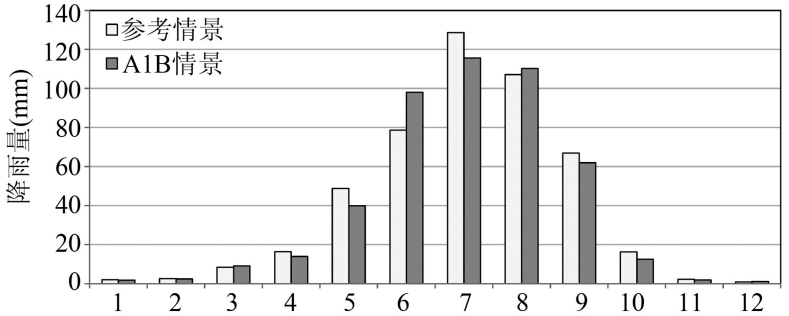

(a)上游

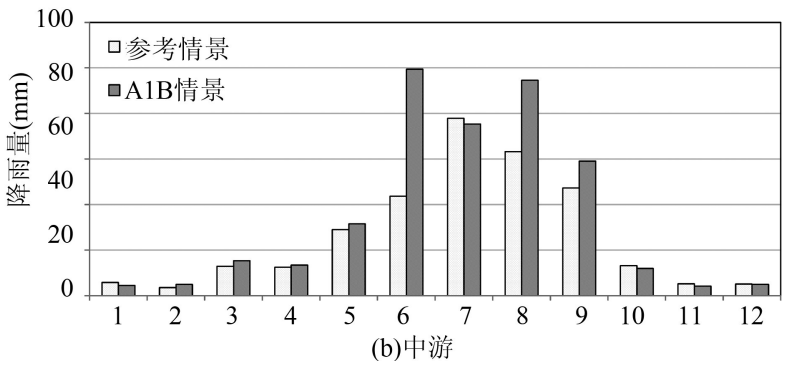

图 10 参考情景和 $\mathrm{A} 1 \mathrm{~B}$ 情景下黑河流域中、上游多年年平均 降雨量

Fig.10 Annual precipitation distribution in the upper and middle reaches of Heihe River Basin under the reference and A1B scenarios

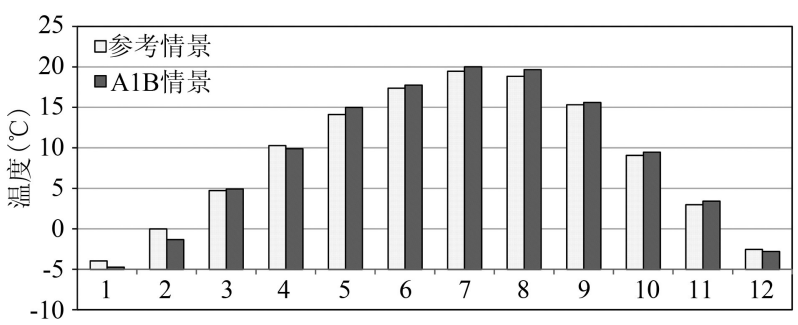

图 11 参考情景和 $\mathrm{A} 1 \mathrm{~B}$ 情景下黑河流域上游多年月平均最高 温度年内分配

Fig.11 Monthly average maximum temperature distribution in the upper reaches of Heihe River Basin within the study years under the reference and $\mathrm{A} 1 \mathrm{~B}$ scenarios

更高, 温度的差异也是导致黑河流域上游未来河川 径流变化的原因之一。

不考虑土地利用变化, 相对于参考情景, 模拟 的 A1B 情景下黑河流域中游模拟的 2011-2030 年 年平均河川径流呈明显增加趋势, 相对于参考情 景, 模拟的 2011-2030年年平均河川径流年内分配 在各月份 (除 5 月份) 差异较明显(图 9(b))。黑河 流域中游河川径流分别受上游来水, 中游降水量和 温度的影响。A1B情景下中游未来多年年平均降 雨量年内分配如图 10(b) 所示, 相对于参考情景, 6-9 月降雨增加, 上游来水增加, 中游河川径流也相 应的增加; 12 月至翌年三月, 降水和上游来水差异
不明显, 但是, 中游河川径流在这段时间明显增加, 这是因中游在这段时间停止灌溉, 前期的灌溉水回 归入河道使河川径流在这段时间明显增加。

A1B 情景下考虑土地利用变化。黑河流域上 游 2011-2030 年年平均河川径流量略小于不考虑土 地利用变化的情况, 这是因黑河流域上游未来林地 和草地呈现增加的趋势, 导致上游蒸散发增加, 河 川径流减少, 同时, 由于上游土地利用变化幅度不 大, 因此, 河川径流在两种情况下差异均不是十分 明显。考虑土地利用变化下, A1B 情景下中游 2011-2030年年平均河川径流量略大于在不考虑土 地利用变化的情况, 这是因未来中游耕地退化, 灌 溉用水减少, 导致中游河川径流较大。A1B 情景下 黑河上游及中游未来河川径流量年内分配在考虑 和不考虑土地利用变化两种情况下相似。

(2)低排放情景 (B1)

不考虑土地利用变化, 相对于参考情景, B1 情 景下黑河流域上游 2011-2030 年年平均河川径流呈 明显减少趋势, 这主要是因为 2011-2030年降雨量 在 B1 情景下呈现明显的减少趋势。相对于参考情 景, 2011-2030年河川径流年内分配在在各月份(除 6 月份)均表现减少的趋势(图 12(a))。

不考虑土地利用变化, 相对于参考情景, B1 情 景下黑河流域中游2011-2030年年平均河川径流呈 微弱的减少趋势, 而中游降雨呈现增加的趋势, 导

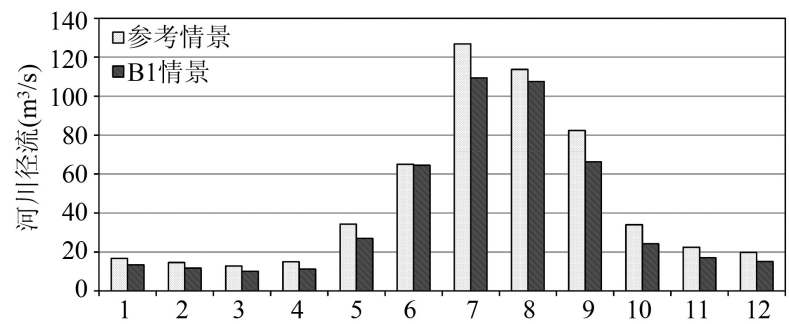

(a) 上游

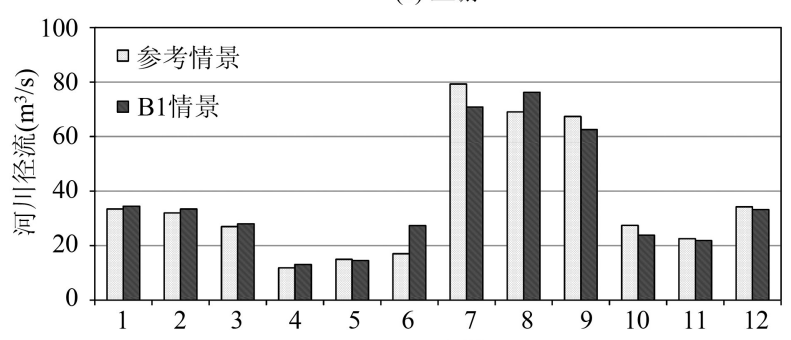

(b) 中游

图 12 参考情景和 B1 情景下黑河流域中、上游多年年平 均河川径流年内分配

Fig.12 Annual streamflow distribution in the upper and middle reaches of Heihe River Basin under the reference and B1scenarios 
致中游河川径流增加的原因是上游来水在 $\mathrm{B} 1$ 情景 下明显减少。相对于参考情景, 中游 2011-2030年 年平均河川径流年内分配在 6-9 月变化比较明显, 其他月份变化不大(图 12(b))。

考虑土地利用变化, B1 情景下黑河流域上游 2011-2030年年平均河川径流量略小于不考虑土地 利用变化的情况。考虑土地利用变化下, B1 情景下 中游 2011-2030年年平均河川径流量小于不考虑土 地利用变化的情况, 这是因为未来中游耕地退化, 灌溉用水减少, 导致径流增加, 但是林地和草地面 积增加, 蒸散发增加, 导致径流减少, 而且林地和草 地增加导致中游径流减少量大于由于耕地减少导 致的径流增加量。 $\mathrm{B} 1$ 情景下黑河上游及中游未来 河川径流量年内分配在考虑和不考虑土地利用变 化两种情况下相似。

\section{(3)情景分析}

不考虑土地利用变化, 相对于参考情景, A1B 情景下黑河流域上游 2011-2030年年平均河川径流 呈微弱减少趋势, 而在 B1 情景下呈现明显的减少 趋势。A1B 情景下上游2011-2030年年平均河川径 流的年内分配在 5-10月变化较明显, B1 情景下除 6 月份, 其他月份均明显地表现为减少的趋势。

不考虑土地利用利用变化, 相对于参考情景, A1B 情景下黑河流域中游 2011-2030年年平均河川 径流呈明显增加趋势, 而在 B1 情景下呈现微弱减 少趋势。相对于参考情景, A1B 情景下中游 20112030 年年平均河川径流在各月份均呈现增加的趋 势, 而 B1 情景下, 在 6-9 月变化比较明显, 其他月份 变化不大。分析表明即使在同一情景下, 不同区域 的水文响应也可能具有明显的差异性。

考虑土地利用的变化, 黑河流域上游 20112030年年平均河川径流在 A1B 情景及 B1 情景下均 小于不考虑土地利用变化的情况。考虑土地利用 变化, 中游河川径流在 $\mathrm{A} 1 \mathrm{~B}$ 情景下, 大于不考虑土 地利用变化的情况, 而在 B1 情景下要小于不考虑 土地利用变化的情况, 因此, 结果表明土地利用变 化可能加剧气候变化的水文响应, 也可能削弱气候 变化的水文响应, 即土地利用变化对气候变化的水 文响应具有双向的(加剧和削弱)影响。

\section{4 结论}

本研究通过耦合 Dyna-CLUE 模型和 SWAT 模
型, 选择政府间气候变化专门委员会 (IPCC, 2000) 发布的两个温室气体排放情景 (A1B 和 B1), 对黑河 流域中上游土地利用变化及水文响应进行多情景 分析, 得到以下主要结论:

(1)通过黑河流域中上游及张掖地区两个空间 尺度的土地利用现状图对 Dyna-CLUE 模型进行验 证, 表明该模型具有很好的适用性。通过黑河流域 中上游两个径流观测站 (莺落峡和正义峡) 的径流 数据对 SWAT 模型校准和验证, 结果表明该模型模 拟结果比较满意, 达到了模拟精度的要求。

(2) 土地利用变化情景分析表明, 不同排放情 景下未来黑河流域中上游土地利用变化幅度均不 大, 同一排放情景下土地利用变化具有明显的区域 特点。生态用地 (林地和草地) 在低排放情景 (B1) 的面积大于高排放情景 (A1B)。

(3) 水文响应情景分析表明, 只考虑气候变化, 相对于参考情景, 高排放 A1B 情景下黑河流域上游 2011-2030年年平均河川径流呈微弱减少趋势, 而 在低排放 B1 情景下呈现明显的减少趋势; 而在中 游, 2011-2030 年年平均河川径流在 A1B 情景下呈 明显增加趋势, 在 B1 情景下呈现微弱减少趋势。 如果综合考虑气候变化和土地利用的变化, 黑河流 域上游出口河川径流在 2 种排放情景下均小于不考 虑土地利用变化的情况, 而中游河川径流在 A1B 情 景下大于不考虑土地利用变化的情况, 在 B1 情景 下要小于不考虑土地利用变化的情况, 这表明了排 放情景下气候变化和土地利用变化导致流域水文 水资源的变化, 而土地利用变化可能加剧或削弱气 候变化导致的水文响应。

\section{参考文献:}

[1] 程国栋,赵传燕.干旱区内陆河流域生态水文综合集成研 究[J].地球科学进展,2008,166(10):1005-1012.

[2] 廉宁霞. 试论黑河流域的生态环境及其保护[J].甘肃农业 科技,2008,389(5):34-36.

[3] 张法霖,王金叶, 常宗强. 黑河流域生态环境建设与和谐社 会构建[J].中国水土保持,2006(5):15-17.

[4] 程国栋.黑河流域可持续发展的生态经济学研究[J].冰川 冻土,2002,24(4):335-343.

[5] 孙力炜, 张勃, 张建香, 等. 内陆河流域土地利用/覆盖变化 的生态效益评价一以疏勒河中下游地区为例 [J]. 干早 区资源与环境,2013,27(3):80-85.

[6] Cammerer H, Thieken A H, Verburg P H. Spatio-temporal dynamics in the flood exposure due to land use changes in the Alpine Lech Valley in Tyrol (Austria)[J]. Natural Haz- 
ards, 2012,1-28.

[7] Mango L M, Melesse A M, Mcclain M E, et al. Land use and climate change impacts on the hydrology of the upper Mara River Basin, Kenya: Results of a modeling study to support better resource management[J]. Hydrology and Earth System Sciences, 2011,15(7):2245.

[8] Park J Y, Park M J, Joh H K, et al. Assessment of MIROC 3. 2 HiRes climate and CLUE-s land use change impacts on watershed hydrology using SWAT[J]. Transactions of the ASABE, 2011,54(5):1713-1724.

[9] 蒙吉军,吴秀芹,李正国. 黑河流域 1988-2000年土地利用/ 覆被变化研究 [J].北京大学学报:自然科学版,2005,40(6): 922-929.

[10] 李传哲,于福亮,刘佳,等.近 20 年来黑河干流中游地区土 地利用/覆被变化及驱动力定量研究 $[\mathrm{J}]$. 自然资源学报, 2011,26(3):353-363.

[11] 姜朋辉, 赵锐锋, 赵海莉, 等.1975 年以来黑河中游地区土 地利用/覆被变化时空演变 [J].生态与农村环境学报, 2012,28(5):473-479.

[12] 张华,张勃.不同水资源情景下干早区未来土地利用/覆 盖变化模拟一以黑河中上游张掖市为例 $[\mathrm{J}]$.冰川冻 土,2007,29(3):397-405.

[13] 吴志勇,郭红丽,金君良,等.气候变化情景下黑河流域极 端水文事件的响应[J].水电能源科学,2010,28(2):7-9,46.

[14] 陈亮. 基于区域气候模式和 VIC 模型的黑河流域陆气相 互作用研究[D].兰州: 兰州大学,2011,1-69.

[15] Liston G E, Elder K. A meteorological distribution system for high-resolution terrestrial modeling (MicroMet) [J]. Journal of Hydrometeorology, 2006,7(2):217-234.

[16] Verburg P H, Overmars K P. Combining top-down and bottom-up dynamics in land use modeling: Exploring the future of abandoned farmlands in Europe with the Dyna-CLUE model[J]. Landscape Ecology, 2009,24(9): 1167-1181.

[17] Verburg P H, Overmars K P, Huigen M G A, et al. Analysis of the effects of land use change on protected areas in the Philippines[J]. Applied Geography, 2006,26(2): 153-173.

[18] Verburg P H, Soepboer W, Veldkamp A, et al. Modeling the spatial dynamics of regional land use: The CLUE-S
model[J]. Environmental Management, 2002,30(3): 391-405.

[19] 赵英时. 遥感应用分析原理与方法 $[\mathrm{M}]$. 北京:科学出版 社,2003,203-208.

[20] Gassman P W, Reyes M R, Green C H, et al. The soil and water assessment tool: Historical development, applications, and future research directions[J]. Transactions of the ASABE, 2007(50):1211-1250.

[21] 余文君.SWAT 模型在黑河山区流域的改进与应用[D]. 南京:南京师范大学,2012,1-50.

[22] 李呈罡. SWAT 模型在黑河中上游流域的改进与集成模 拟研究[D].南京:南京师范大学,2012,1-51.

[23] 黄清华,张万昌.SWAT 分布式水文模型在黑河干流山区 流域的改进及应用[J].南京林业大学学报(自然科学版), 2004,28(2):22-26.

[24] Diaz-Nieto J, Wilby R L. A comparison of statistical downscaling and climate change factor methods: Impacts on low flows in the River Thames, United Kingdom[J]. Climate Change, 2005,69(2):245-268.

[25] Hay L E, Wilby R L, Leavesley G H. A comparison of delta change and downscaled GCM scenarios for three mountainous basins in the United States [J]. JAWRA Journal of the American Water Resources Association, 2000, 36(2):387-397.

[26] Morita T. Greenhouse gas emission scenario database ver 5.0 operating manual[EB/OL]. Japan: National Institute for Environmental Studies Center for Global Environmental Research, 1999.

[27] Morita T. Emission scenario database prepared for IPCC Special Report on Emission Scenarios[R]. IPCC, 1999.

[28] 李娜, 颜长珍, 廖杰. 黑河中游分水前后林草变化动态监 测 [J].生态学杂志,2009,28(9):1719-1722.

[29] Moriasi D N, Arnold J G, Van Liew M W, et al. Model evaluation guidelines for systematic quantification of accuracy in watershed simulations[J]. Transactions of the ASABE, 2007,50(3):885-900.

[30] Henriksen H, Troldborg L, Nyegaard P, et al. Methodology for construction, calibration and validation of a national hydrological model for Denmark[J]. Journal of Hydrology, 2003,280(1):52-71. 


\title{
Coupling LUCC and Hydrological Models to Predict Land Use Change and Hydrological Response under Multiple Scenarios
}

\author{
ZHANG Ling $^{1,2}$, NAN Zhuotong ${ }^{1 *}$ and YU Wenjun ${ }^{1}$ \\ (1. Cold and Arid Regions Environmental and Engineering Research Institute, CAS, Lanzhou 730000, China; \\ 2. University of Chinese Academy of Sciences, Beijing 100049, China)
}

\begin{abstract}
Land use and climate change under emission scenarios and their hydrological responses are some most concerned issues in watershed management. By coupling a land use land change model, Dyna-CLUE, and a hydrological model, SWAT, this paper predicts land use changes and hydrological responses in the upper and middle reaches of Heihe River Basin (HRB) under two emission scenarios, A1B and B1, from the Intergovernmental Panel on Climate Change (IPCC). After calibration, the models validate their applicability in the study area. Scenario analysis shows no obvious land use changes in the upper and middle reaches of HRB with both emission scenarios while with a same scenario, land use changes present regional characteristics. In terms of future hydrological responses, if we only consider the climate change, comparing to the reference scenario that is created with historical data of 1990 2009, mean annual streamflow in the period of 2011 2030 shows a slight decrease in the upper reaches of HRB and an obvious increase in the middle reaches under the high emission scenario (A1B), and an obvious decrease and a slight decrease respectively under the low emission scenario (B1). Under a same scenario, hydrological responses present regional characteristics in the upper and middle reaches. As climate change also causes land use change which in turn impacts hydrological responses, we compare the joint impact case with the case of climate change only. Mean annual streamflow in the period of 2011 2030 becomes less in the upper reache and greater in the middle reache under the high emission scenario (A1B), and less in both reaches under the low emission scenario (B1). The analysis indicates that climate and land use changes under emission scenarios in the study area will lead to hydrological and water resources changes and the land use change may intensify or weaken hydrological responses caused by climate change.
\end{abstract}

Key words: model coupling; land use change; hydrological response; scenario analysis

*Corresponding author: NAN Zhuotong, E-mail: nztong@1zb.ac.cn 